\title{
双子分娩牛の発情回帰および血中代謝産物濃度に及ぼす 飼料給与量の影響
}

\author{
米内美晴・下司雅也・坂口 実・鈴木 修* \\ 農林水産省東北農業試験場，盛岡市 020-01
}

(1994. 4. 11 受付)

\begin{abstract}
要 約 双子を分婏・哺育した黒毛和種, 日本短角種崔牛 17 頭について分婏後の䌘殖機能回復と血 中代謝産物濃度の変化を調查し, 単子を分婏・哺育した 20 頭よ比較検討した。双子分婏牛は分婏前 2 力

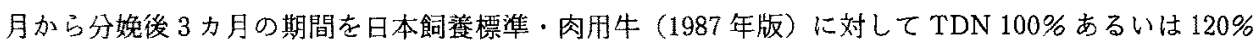
で飼養した，得られた結果は以下の通りである．TDN 100\%を給与した双子分婏牛（6頭）の分婏から初 回排卵までの日数は対照の単子分婏牛とほとんど差がなかったが, 初回発情までの日数は有意 $(\mathrm{P}<$ 0.01）に長くなったままた，血中のグルコース（GLU），ヒドロキシ酪酸（3-HB）および遊離脂肪酸

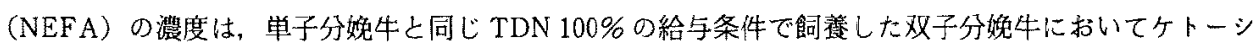
ス様の翼常值を示したあのああり，これらの双子分媿牛は明らかにエネルギー不足に陥っていた，一方， TDN 120\% で飼養した双子分婏牛（11 頭）では，血中のGLU，3-HB おょびNEFA の濃度の推移は学 子分娩牛の値に近く、エネルギー不足の徵候を認めなかった，また，分娩から初回排卵および初回発情 までの日数も単子分婏牛よの差が小さくなった．以上の結果加ら，黑毛和種および日本短角種の双子分 婏牛においては日本飼養標準に示された養分要求量に対して $120 \%$ で飼養することで，エネルギー不足 に上る分娩後の発情回㷌遅延を改善し得る上考えられた。
\end{abstract}

日畜会報, 65 (10)：968-974，1994

近年，肧移植技術や性腺刺激ホルモン投与に上る方誘起 多胎技術を利用した牛の双子生産が行なわれるように

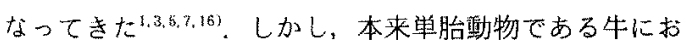
いては，双子をを妊娠・分婏・晡育することは過剩な生理 的負担となり，流死産，難産，後産停滞，繁殖機能回復 遅延等の様々な異常が起り易くなることが報告されてい $3^{5,8,25)}$.

肉用繁殖牛の管理においては 1 年末満の分婏間隔が望 ましいが，双子分婏牛においては主に繁殖機能回復の遅 延によって分媿間隔が延長しやすいため，1年1産のサ イクルで連産させるには，これを回避する技術が必要と される。

単子分婏牛では分娩後の繁殖機能回復に対して分婏前 後の飼鉒条件が影響を伋代すこ上が報告されてい $ろ^{17-19)}$. さらに双子妊娠牛では娃娠末期の胎児 2 頭の発 青および分婏後の双子哺育期にお引る授乳量の增加等に よって養分要求量が増加することが報告されてい
$3^{10.25)}$ ．したがって，従来の飼育管理条件下では必要な

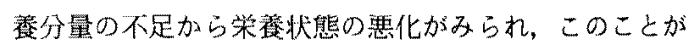
繁殖機能回復の遅延をむたらす重要な要因になると若元 られるが，双子分婏牛の分婏前後における策尊条件上詳 細な繁殖機能回復の様相ならびに代謝状態との関係につ いての報告は見当らない，

そこで，本研究では給与水準を変えて飼養した双子分 婏牛の繁殖機能回復状況を調べると亡もに，分婏前後の 血中代謝産物濃度の変化加ら代謝状態を把握し, これら 在筆子分婏牛之比較することによって，1年１産を可能 にする双子生産牛の飼料給与量を明らかにしようとし た.

\section{材料および方法}

供試牛と飼養管理

東北農業試駼場畜産部で 1989 年から1992 年に加けて 双子または単子を分娩した黒毛和種経産牛 32 磌および

* 現所属: 農林水産省草地試験場, 栃木県西那須野町 329-27 
日本短角種経産牛 5 頭を用いた。双胎好娠牛は肧移植ま たは語起多胎法によって作出し，妊娠 46〜88 日に超音 波診断法によって胎子数を確認した。試鈳期間は分婏予 定 2 力月前加ら分娩後 3 力月とした：単子分婏牛 20 頭 (以下単子区) に対する飼料給与量は日本飼養標準 - 肉 用牛（1987 年版）に従い，維持のTDN 量に胎児発有ま たは授乳に要するTDN 量を加えた量とした。維持の TDN 量は，分婏前 2 力月と分婏直後の体重测定值に基 づき算出した，授乳に要するTDN 聂の算定基礎とした 哺乳量は黒毛和種は日量 $7 \mathrm{~kg}$, 日本短角種は $10 \mathrm{~kg}$ とし た，双子分婏牛については飼料給与量を変えた 2 区を設 けたすなおち，17頭中 6 頭は試験期間を通して単子分 婏牛之同量の飼料給与を行ない（以下双子 $100 \%$ 区), 他 の11頭には同樣にして算出したTDN 量の $120 \%$ を給 与した (以下双子 $120 \%$ 区)。なお，維持の TDN 量に妊 娠末期の胎児発育に要するTDN 量の 2 倍量を加えた総 量は単胎妊娠牛に給与すべきTDN 総量の, 約 $120 \%$ で ある。また分媿後は授乳に要するTDN 量に維持の TDN 量を加えたTDN 絰量の $120 \%$ 給与した。飼料は コーンサイレージを主体として牧乾草と濃厚叙料を組み 合せて朝夕 2 回に分けて個別給与した。 給与量の計算に は日本飼盖標準・肉用牛 (1987 年版) 記載の飼料成分表 を用いた。

\section{調査項目}

1）分婏後の繁殖機能回復：分娭後 7 日目から直晹検 查に上る卵巣の触診を連日，また， 発情行動の観察を 1 日 2 回実施し, 分婏後の初回排卵日之初回発情日を把握 した，初回発情日はスタンディング発情の認められた日 とした.

2）体重測定：体重は試験期間中週 1 回測定した。な お, 分婏後 12 時間以内に測定した体重を分婏直後体重 とした.

3）血中代謝産物濃度の測定：採血は分婏前は週 2 回
行なった，分婏後は分婏日を0日として $1 ， 3 ， 5 ， 7 ， 10$ 日目とそれ以後は週 1 回行なった. グルコース (GLU), ヒドロキシ酪酸 (3-HB) 測定に用いる血液サンプルは パリンナトリウム加真空採血管を用い, 遊雌脂肪酸 (NEFA) 測定用サンプルはEDTA 加真空採血管を用い て朝の飼料給与前に钼静脈上り採血し，直ちに血嶈を分 離して分析時までー $40^{\circ} \mathrm{C}$ で保存した，分析は日立705 型 自動分析機を用いて，GLU濃度はム夕ローゼ・グル コースオキシダーゼ法（和光純薬，日立 705 型用試薬）, NEFA 濃度はアシルCOA シンセターゼ・アシルCOA オキシダーゼ法（和光純菜, 日立 705 型用試薬）によ。 て測定した. 3-HB 濃度は血漿を過塩素酸で除蛋白した 後にキット(ベーリンガー・マンハイム山之内， F-キッ ト)を用いて測定した。

有意性の検討は $\mathrm{t}$ 検定によって行なった，

$$
\text { 結果 }
$$

表 1 亿分媿後の繁殖機能回復の状況を示した。分婏か ら初回排卵までに要した日数はいずれの区も約 30 日で 3区間に有意差を認めなかった。しかし, 分娩後の発情 回帰日数岋双子 $100 \%$ 区は約 68 日で単子区の約 39 日よ り 29 日 $(\mathrm{P}<0.01)$ ，また，双子 $120 \%$ 区の約 47 日より 21 日荤かった $(P<0.01)$. な极双子 $100 \%$ 区の分婏牛は， 初回排卵日数は他区之差がな加ったが，初回排卯後も無 発情排卵を $1 \sim 2$ 回繰り返し，発情回帰は大きく逑延し t.

分婏直後体重を基準（100\%）として換算した分婏前 後の相対的体重推移を図 1 に示した、妊娠末期 2 力月間 は各区と6に体重增加を示し，双子100\%区扰上び双子 $120 \%$ 区は単子区に比べ, 分娩直後体重に対する体重比 が平均 6\%大きかった $(\mathrm{P}<0.01)$. 双子 100\%区と双子 120\%区の間に差は認められなかった. 分婏後 3力月間 では，単子区は体重の大きな增減を示さず，分婏直後の

Table 1. Postpartum interval day from parturition to the first ovulation and estrus in twinning cows

\begin{tabular}{|c|c|c|c|c|}
\hline \multirow{2}{*}{$\begin{array}{l}\text { TDN* for } \\
\text { experimental } \\
\text { period }\end{array}$} & \multirow{2}{*}{$\begin{array}{l}\text { Type of } \\
\text { pregnancy and } \\
\text { rearing calves }\end{array}$} & \multirow{2}{*}{$\begin{array}{l}\text { No. of } \\
\text { cows }\end{array}$} & \multicolumn{2}{|c|}{ Interval days from parturition to } \\
\hline & & & $\begin{array}{l}\text { 1st ovulation } \\
\text { (Mean } \pm \mathrm{SD})\end{array}$ & $\begin{array}{c}\text { 1st estrus } \\
\text { (Mean } \pm \mathrm{SD})\end{array}$ \\
\hline $100 \%$ & single & 20 & $29.6 \pm 12.7$ & $39.3 \pm 9.3^{\mathrm{a}}$ \\
\hline $100 \%$ & twin & 6 & $31.2 \pm 13.5$ & $68.2 \pm 10.8^{b}$ \\
\hline $120 \%$ & twin & 11 & $28.6 \pm 10.3$ & $47.3 \pm 10.1^{c}$ \\
\hline
\end{tabular}

* Use of Japanese Feeding Standerd for Beef Cattle (1987)

Different superscript within columns denote significant differences.

$(a-b: P<0.01, \quad b-c: P<0.01 \quad a-c: P<0.05, \quad t-$ test $)$ 


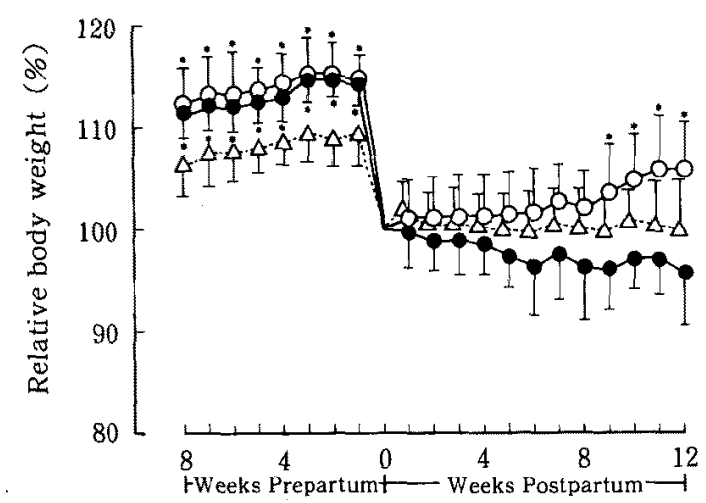

Fig. 1. Average relative body weight change of the dams for experimental period, 0 to 8 week prepartum and 0 to 12 week postpartum.

- : dams produced twin calves was fed a $100 \%$ diet of the requirements for TDN.

$O$ : dams produced twin calves was fed a $120 \%$ diet of the requirements for TDN.

$\triangle$ : dams produced single calf was fed a $100 \%$ diet of the requirements for TDN.

Significantly different from the group of dams produced single calf. $(*: \mathrm{p}<0.01, \mathrm{t}-$ Test $)$

体重を維持した，双子 $100 \%$ 区の体重は減少する傾向に あった，また，双子 $120 \%$ 区は分娩後 6 週ころまで分婏 直後体重を維持したのち体重堌加に転し，分婏後 9 週以 後に沶いては分婏直後体重に対する相対体重として約 6\%の体重增加を示し，双子 100\% 区との間に有意差（P く0.01）を認めた.

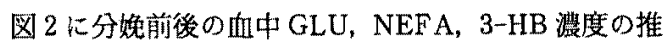
移を示した，GLU濃度は各区とす分婏前 1 週まで徐々 に低下した。分婏前 1 週での GLU 濃度は単子区，双子 $100 \%$ 区およよ゙双子120\%区がそれぞれ 66.9土5.4，58.0 \pm 11.5 および $62.3 \pm 2.6 \mathrm{mg} / \mathrm{d} l$ であり，双子 $100 \%$ 区の

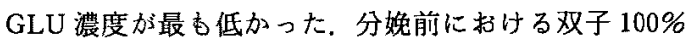
区の濃度低下の傾向は分娩前 1 週が最す顕著で，正常值 の下限 $(45 \mathrm{mg} / 100 \mathrm{~m} l)$ より低い $31.0 \mathrm{mg} / 100 \mathrm{~m} l$ まで低 下した個体が観察された，分婏後は各区とあGLU濃度 は急激に上㫧し，分娩後 1 日目に試験期間にお计万最高 値（約 72 75 $\mathrm{mg} / 100 \mathrm{ml}$ ）を示した，その後の GLU 濃 度は単子区执よび双子 $120 \%$ 区では一定の濃度で安定し て推移したが，双子 100\%区では約 63〜 73 mg/100 ml の濃度範囲にわたる変動が観察された。 しかし，分婏後 の GLU 濃度には 3 区間に有意差は認められなかった。

血中 3-HB 浱度の推移については，単子区では分婏前 後を通じて大きな濃度变化は認められなかった，双子
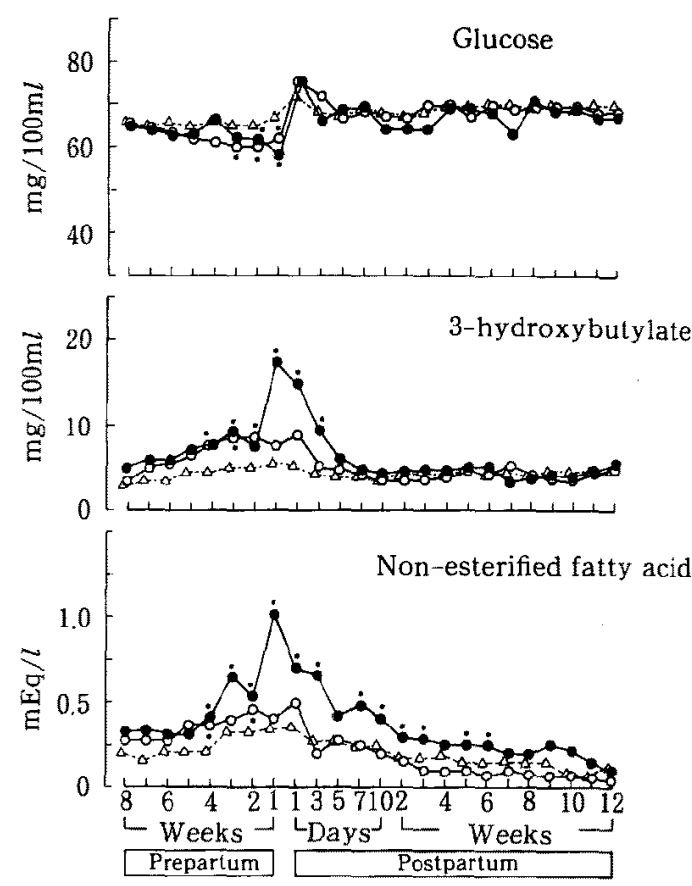

Fig. 2. Change of mean concentration of blood metabolites in the dams for experimental period.

- dams produced twin calves was fed a $100 \%$ diet of the requirements for TDN.

$\mathrm{O}$ : dams produced twin calves was fed a $120 \%$ diet of the requirements for TDN.

$\Delta$ : dams produced single calf was fed a $100 \%$ diet of the requirements for TDN.

Significantly different from the group of dams produced single calf. $\left({ }^{*}: p<0.01, t\right.$-Test)

$100 \%$ 区蛙分婏前 4 週加ら上昇を示し，分婏前 1 週にお いて最高値を示した．双子 $120 \%$ 区む同様の濃度推移を 示したが，分婏前 1 週における急激な濃度上昇は観察さ れなかった，分娩前 1 週に扔ける単子区，双子 100\%区 および双子 $120 \%$ 区の3-HB 惯度はそれぞれ5.21土 $2.20 ， 17.11 \pm 15.35$ および $7.43 \pm 4.27 \mathrm{mg} / 100 \mathrm{ml}$ で，双子 100\%区が他の 2 区より 2 倍以上の高嶩度を示した（P $<0.01)$. 双子 100\%区拈上び双子 120\%区の3-HB 濃度 が算子区上同レ心゙ルまで低下したのは分婏後 1 週以降で あった。

血中NEFA 濃度は 3 区之も分婏までは上昇し，分娩 後は低下した．3区の中では双子 100\% 区が分婏前 4 週 ころから急激に上昇し，他の 2 区と明らかに異なる样相 を示した，単子区，双子100\%区および双子 120\%区の 分婏前 1 週の NEFA 濃度はそれぞれ $0.34 \pm 0.15 ， 1.02 \pm$ 
0.71 および $0.41 \pm 0.18 \mathrm{mEq} / l$ であり，双子 $100 \%$ 区が他 の 2 区に比べて 2 倍以上の高濃度を示し，また，分婏前 4 週 分婏後 6 週まで単子区上り有意 $(\mathrm{P}<0.01)$ に高い 值を示した，双子 $120 \%$ 区の NEFA 濃度も分婏後 1 日 までは単子区に比べて高い傾向が認められたが，分婏後 3 日以後は単子区と同様の濃度推移を示した。

\section{考察}

双子 $100 \%$ 区の発情回帰日数は平均 68.2 日で明らか に他の区より遅く，1年 1 産を目標として分婏後 80 日以 内の受胎を目指す場合，受胎の機会はきわめて少なくな ると考えられる．これに対して，双子 $120 \%$ 区の発情回 㴆日数は平均 47.3 日と双子 $100 \%$ 区に比べて約 20 日短 くなった，双子 $100 \%$ 区は，分婏後の初回排卵日数は荤 延しなかったにもかかわらず，初回排卵以後も無発情排 卵を繰り返し発情再㷌が大幅に遅延するが，20\%の飼料 增給によってこの無発情排卵の繰り返しを防止できるこ とが明らかとなった。

分娭後初回排卵末での日数に関して，WHEELER et al. ${ }^{21)}$ は飼料の自由摂取条件下で算子分婏牛上双子分 婏牛を比較し，双子分婏牛が遅い傾向にあったが両者に 有意差のなかったことを報告している. SHORT et al. ${ }^{14\rangle}$ は授乳は卵胞発育に影響しないと報告しており， LISHMAN et al. ${ }^{11}$ は分婏後に体重が減少するはどの低栄 養条件であってす卵胞発育に影響はないことを報告して いる. 鈴木·佐藤 ${ }^{157}$ は，単子分婏牛の分婏後初回排卵ま での日数は，分婏直後に離乳して母牛に対する栄養的な 負何および吸乳刺激がない場合には顕著に早期化する が，子牛に授乳している母牛は通常の栄養条件下であれ 代授乳期間の長短にかかわらず分婏後 30 日ころまでに 初回非卵が起ると述べている. 本試験においても双子 100\%区の栄養状態は他の 2 区に比較して分婏前後を通 じて低下していたと考えられるが，初回排卵は連れるこ とはな加た。これらのこと加ら，母牛の栄養状態と㗘 乳強度が分婏後初回排卵までの日数に大きく影響するこ 上はないと考えられる。

一方，分婏後発情回帰までの日数では 3 区間に差が認 められ，双子100\%区では発情回帰が著しく遅延した。 授乳中の单子分婏牛では，分婏前後の高栄盖条件で発情 回婦が早まり，過度の低栄養条件では遅延することが報 告さ机ている ${ }^{17,19)}$ ，このように授乳中の母牛では栄養条 件は発情回帰日数に明らかに影響している。このここに 関して，高栄養条件では分婏後の LH 分泌能が高まって いるという報告がある ${ }^{4,9)}$ が，発情回帰との関係を含む その詳細な機構はまだ明らかにされていない。
授乳は分婏後の発情回㷌を遮延させるという報告がな されている ${ }^{20,23)}$ 一方で，影響しないという報告もあ

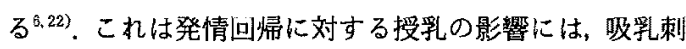
激による性腺分泌ホルモンの分泌抑制と，授乳による母 牛の栄煎状態の低下の二つの要因が含まれ，これらを分 離して吸乳刺激単独の影響を評価することが難しいため と考えられる，双子分婏牛は単子分婏牛より多くの吸乳 刺激を受けると考えられるため，授乳による低栄養状態 を改善しても発情回帰は㜊延する可能性が考えられた が，本試験では発情回帰遲延が飼料增給によって防止さ れた.このことは本試験の双子分婏牛の発情回㷌遅延の 原因として必要養分量の不足が吸乳刺激の影響より大き 加たことを示唆していると考えられる.

双子 120\%区之単子区では初回排卵日数に差はなく， 両区ともほ济全牛で分浼後 2 回目の排莭から発情が観察 されたが，双子 $120 \%$ 区は初回発情日が約 8 日漣かっ た.これは，初回と2回目排卵の間隔が異なったためで あり，単子区においては最初の排卵間隔が通常の排卯周 期より短周期上なる個体が多かったことによる，分婏後 の排眮間隔については, 初回排卵後の黄体の持続期間は 短い場合が多く，分婏後最初の排卵間隔は短周期となり やすいことが報告されている ${ }^{12,18)}$ ，また，飼料を自由捸 取とした条件で双子生産牛は単子生産牛に比較して最初 の非卵間隔が長い傾向にあるという報告があり ${ }^{21)}$, 本試 鈳の結果に類似している。この原因は明らかではない が，栄養条件の変化による血清脂質の変動が分婏後の黄

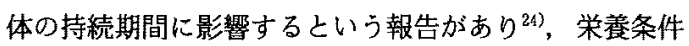
の影響も考虑し得る要因と考元られる。

血中 GLU，NEFA，3-HB 濃度の変化加ら個体の土ネ ルギー状態を推定することが可能であり ${ }^{13)}$, エネルギー 不足の状態では, 血中 NEFA 濃度おょびる-HB 濃度は 上昇し，GLU 濃度は低下するが，双子 100\%区は他の 2 区と比較して長期にわたってェネルギー不足状態であっ たことが示された．特に奼娠末期にはGLUの正常值の 下限以下への低下および，NEFA，3-HBの著しい上昇 を示す個体が観察され，発症は観察されなかったがケ トーシスにきわめて類似した状況と考えられた．分婏後 においては双子 $100 \%$ 区の NEFA 濃度は分媿後 6 週こ ろまで他の 2 区上り明らかに高值を持綂し，このことは 双子 $100 \%$ 区において必要なエネルギーの不足分老体脂 肪を動員することで補っていたことを示している。

これに対して，双子 120\%区の血中代謝産物濃度は妊 娠末期に軽度のエネルギー不足状態の所見を示したが， 分婏後は早急に改善され，20\%の飼料增給によって分婏 前後を通じてェネルギー状態がほぼ通常の状態に保持さ 
れたことがうかがわれた。

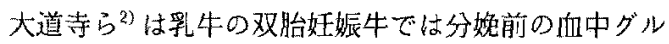
コース漕度が単胎妊娠牛に比較して低下すると報告して いるが，その原因としては子宮が消化管を压迫すること による飼料摆取量の低下を挙げている10). 本試験におい ても妊娠末期に双胎妊娠牛の一部に残食加観察されてお。 り，妊娠の進行に伴う飼料摄取量の低下は双子 $100 \%$ 区 の分婏前のエネルギー不足をさらに琹化させる要因と なった可能性が大きい。しかし，双子 120\%区では飼料 給与量が多かったにもかか⿰らず残食が镜察された個体 は少なく，飼料摂取量の低下に伴うエネルギー不足は軽 度であったと考えられる。

KOONG et al. ${ }^{10)}$ は双子分婏牛の妊娠末期の体重は飼料 を白由提取とした場合，胎児発育に要するエネルギー要 求量が増大する一方で，飼料摄取量が低下するために母 牛自身の体重は低下すると報告している，双子 $100 \%$ 区 は双子 $120 \%$ 区に比較して，分婏前にかなりのエネル ギー不足状態にあったあのと推察されるが，その不足状 㷫を雨区の相対体重推移加らうかがうことはできなかっ た。

分娩後は，双子 $100 \%$ 区は体重を維持できず体重減少 が続いたが，双子 120\%区は体重を維持し，さらに分婏 後 9 週以後には体重增加に転じた，双子を哺育している 牛は，乳量が $39 \%$ 増加することが報告 ${ }^{25)}$ されている。こ の乳量增加の数值が本試験にそのまま適用できるとは考 えられないが，仮に乳量が 40\% 增加した場合の必要 TDN 量を武算すると体重 $500 \mathrm{~kg}$ から550 kg の黒毛和 種母牛では分婏後の哺乳期間に体重を維持するためには 乳量增加分㞭含めて，通常の約 $118 \%$ を必要上すること になり，分婏後における20\%の增給が双子分婏牛の管 理においてほぼ妥当であったと考えられる、なお，本試 験で生産された双子の生時体重を比較すると双子 $100 \%$ 区と双子 $120 \%$ 区では差が無く，分娩前の飼養条件が子 牛の生時体重に影響しなかったことが推察された。 ま た，単子之比較する上双子の生時体重はやや小さい傾向 にあったか，有意差注認められなかった，双子の生時〜 8 週粠までの日增体量は生時体重亡同様に母牛の飼養条 件の影響は認められず，単子の日增体量上り劣る傾向に あった。

以上のことから双子を分婏・哺乳する繁殖牛は, 単子 分婏牛と同じ栄養管理条件下では分娭後の発情回㷌が遅 延するが，その原因は主としてェネルギー不足によるあ のであることが推察された．また，これらの双子分娭牛 に日本飼養標準の示す TDN 要求量に対して $120 \%$ の堌 給赾行うことでエネルギー不足は概如改善され，発情発
現も正常となることが本試験の結果から実証されたよう に思われる。

\section{謝辟}

本研究の実施に際して多大なご協力をいただいた東北 農業試験場業務第 2 科の諸氏に，またご校閲をいただい た古谷 修博士，永井 卓博士に深謝いたします。さら に，貴重な文解をご提供いただいた石川県農業短期大学 泉 德和教授に深謝いたします。

\section{文献}

I) Anderson, G.B., Methods for producing twins in cattle. Theriogenology, 9:3-16. 1978.

2) 大道寺郁子・井関尚子・笠井裕明 - 平田統一・成 田啓司・三宅陽一・金田義宏，乳牛におりる双子 婏出前後の臨床所見，血液性状および血中性ステ ロイドホルモンの变化. 家畜繁殖誌, 39:23-29. 1993.

3) Davis, M.E., W.R. HaRVEY, M.D. BishoP and W. W. Gearheart, Use of embryo transfer to induce twinning in beef cattle: embryo survival rate, gestation length, birth weight of calves. J. Anim. Sci., 67 : 301-310. 1989.

4) Echternkamp, S.E., C.L. Ferrell and J.D. Rone, Influence of pre- and post-partum nutrition on LH secretion in suckled postpartum beef heifers. Theriogenology, $18: 283-295.1982$.

5) Gordon, I., G. Williams and J. Edwards, The use of serum gonadotrophin (P.M.S) in the induction of twin-pregnancy in the cow. J. Agric. Sci., 54 : 143-198. 1962.

6) Hinselwood, M.M., D.J. Dirrschke and E.R. HaUSER, Effect of suckling on the Hypothalamic-Pituitary Axis in postpartum beef cows, Independent of ovarian secretions. Biology of Reproduction, 32:290-300. 1985.

7）磯貝 保·仲西孝敏・佐々木一八・田上順道, 低 单位 FSH および $\mathrm{PGF}_{2 x}$ あるいはその類縁体投与 によるウシの誘起多胎と双子生産。家畜繁殖誌， $37: 105-113.1991$.

8）泉 德和, ウシの双胎. 日畜北陸支部会報， 65 : 11-21. 1992.

9) Killen, J.H., D.W. Forrest, F.M. Byers, G.T. Schelling and C.R. Long, GonadotropinReleasing Hormone induced $\mathrm{LH}$ release in heifers : Effect of nutrition during gestation. J. Anim. Sci., 67 : 496-500. 1989.

10) KoOng, L.J., G.B. Anderson and W.N. GarretT, Maternal energy status of beef cattle during single and twin pregnancy. J. Anim. Sci., 54 : 480-484. 1982. 


\section{双子母牛の発情回㷌と飼料給与量}

11) Lishman, A.W., S.M.J. Allison, R.L. Fogwell, R.L. Butcher and E.K. InskeEP, Follicular development and function of induced corpora lutea in underfed postpartum anestrous beef cows. J. Anim. Sci., 48 : 867-875. 1979.

12) Odde, K.G., H.S. WARd, G.H. KIRACOFE, R.M. MCKEE and R.J. KiTTOK, Short estrous cycles and associated serum progesterone levels in beef cows. Theriogenology, $14: 105-121.1986$.

13) Russel, A.J.F. and I.A. WRJGHT, The use of blood metabolites in the determination of energy status in beef cows. Anim. Prod., 37 : 335-343. 1983.

14) SHort, R.E., R.A. Bellows, E.L. MOODY and B.E. HOWLAND, Effect of suckling and mastectomy on bovine postpartum reproduction. J. Anim. Sci., $34: 70-74.1972$.

15）鈴木 修・佐藤匡美, 早期離乳牛における分婏後 の繁殖機能及び血中プロジェステロン濃度の変 化。日畜会報, 51 : 760-765. 1980 。

16）鈴木 修・下司雅也・米内美晴 - 坂口実, HMG 低笚位投与に上万肉用牛の誘起多胎. 東北 農試研報, 86:93-99. 1993.

17）高橋政義・菊池武昭・久馬 忠, 繁殖牛飼養にお ける高栄養が分婏後の生殖機能回復に及ぼす影 響. 東北農業研究, $29:$ 147-148. 1981.

18）高橋政義 - 久馬 忠 - 菊池武昭 - 田中彰治, 黒毛 和種の早期離乳牛における生殖機能の産歴差につ いて, 東北農業研究, 31 : 161-162. 1982.

19）高橋政義 - 菊池武昭 - 久馬 忠・滝沢静雄, 黒毛

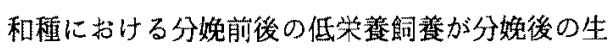
殖機能回復に及ばす影響. 東北農試研報，69：8193. 1984.

20) Verne La Voie, D.K. Han, D.B. Foster and E.L. MOODY, Suckling effect on estrus and blood plasma progesterone in postpartum beef cows. J. Anim. Sci., 52 : 802-812. 1981.

21) WheEler, M.B., G.B. Anderson, R.H. Bondurant and G.H. STABENFELDT, Postpartum ovarian function and fertility in beef cattle that produce twins. J. Anim. Sci, $54: 589-593.1982$.

22) Williams, G.L., J. Kotwica, W.D. Slanger, D.K. OLSON, J.E. TILTON and L. J. JOHNSON, Effect of suckling on pituitary responsiveness to gonadotropin-releasing hormone throughout the early postpartum period of beef cows. J. Anim. Sci., 54 : 594-602. 1982.

23) Williams, G.L., F. Talayera, B.J. Petersen, J. D. KRsCH and J.E. TILTON, Coincident secretion of Follicle-Stimulating Hormone and Luteinizing Hormone in early postpartum beef cows. Biology of Reproduction, 29 : 362-373. 1983.

24) Williams, G.L., Modulation of luteal activity in postpartum beef cows through changes in dietary lipid. J. Anim. Sci., 67 : 785-793. 1989.

25) WyatT, R.D., M.B. Gould and R. TotuseK, Effects of single vs simulated twin rearing on cow and calf performance. J. Anim. Sci., 45 : 1409-1414. 1977. 


\title{
Influence of Nutrition on Reproductive Performance and Blood Metabolite Concentrations in Twinning Beef Cows
}

\author{
Miharu YonaI, Masaya Geshl, Minoru SaKaguchi \\ and Osamu SuzukI* \\ Department of Animal Production, Tohoku National Agricultural \\ Experiment Station, Morioka-shi 020-01
}

The objective of this study was to investigate the effect of levels of nutrition on postpartum reproductive performance in beef cows that produced twin calves. Data were collected from 37 Japanese Black and Japanese Shorthorn after artificial insemination or embryo transfer. Pregnancy was confirmed using the real-time ultrasonic scanning method on Days 46 to 88 of gestation and the number of fetuses was recorded. A group of cows with a single fetus (Group C, 20 cows) was fed a diet conforming $100 \%$ to the Japanese Feeding Standard (JFS) for Beef Cattle (1987) requirements for TDN during the last 2 months of pregnancy. Cows with twin fetuses were divided into two groups and fed either $100 \%$ (Group 1, 6 cows) or 120\% (Group 2, 11 cows) of the JFS diet during the last 2 months of pregnancy. After parturition, the cows in Group $\mathrm{C}$ and 1 were fed $100 \%$ of the requirement, and cows in Group 2 were fed $120 \%$ of the requirement for 3 months. The ovarian activity of the cows was investigated daily by rectal palpation from 7 days after parturition, and estrus behavior was observed twice a day. In order to determine the cows' energy status, blood samples were collected and blood metabolite concentrations (glucose, 3hydroxybutylate, none-esterified fatty acids) during the pre- and post-partum experimental period were analyzed.

Intervals from parturition to the 1st ovulation were not significantly different among the groups. When cows having twin fetuses were fed according to the JFS diet for cows having a single fetus before parturition, the interval from parturition to the 1st estrus became longer than for Group 2 and C. From the measurements of blood metabolite concentrations, it was found that the energy status of the cows in Group 1 was deficient during the prepartum period. On the other hand, the blood metabolite concentrations of Group 2 and $\mathrm{C}$ did not differ during the experimental period.

The results indicate that the 1st ovulation after parturition of twinning cows is not influenced by nutrition, and that the interval from parturition to the 1st estrus of twinning cows can be shortened by a $120 \%$ level of JFS diet.

Anim. Sci. Technol. (Jpn.) 65 (10) : 968-974, 1994

Key words : twinning beef cows, first estrus, first ovulation, TDN, blood metabolites

\footnotetext{
* Present address : Department of Grazing Animal Production, National Grassland Research Institute, Nishinasuno-machi, Tochigi-ken 329-27
} 